\title{
Immunohistochemical Expression of Vitamin D Receptor (VDR) In Prostate Adenocarcinoma in General Hospital Haji Adam Malik Medan in 2017-2018
}

\author{
Zuhri Madriah*, Delyuzar*, Lidya Imelda Laksmi* \\ Department of Anatomical Pathology, Faculty of Medicine, Universitas Sumatera Utara, Medan, Indonesia. *Corresponding Author
}

DOI: 10.29322/IJSRP.11.07.2021.p11558

http://dx.doi.org/10.29322/IJSRP.11.07.2021.p11558

\begin{abstract}
The exposure of ultraviolet and vitamin D serum levels have been linked to prostate cancer. At the cellular level, the main function of vitamin D is mediated by VDR in order to reduce proliferation and increase apoptosis in some malignancy. Objective: To assess the distribution of VDR immunohistochemical expression in prostate adenocarcinoma based on age, PSA value, and histopathological grading. Materials and Methods: This descriptive study with cross sectional approach used 34 samples from paraffin blocks from patients histopathologically diagnosed as prostate adenocarcinoma. Immunohistochemical staining of VDR were perfomed and their expression were determined based on brown color expressed in cytoplasm and nuclei. The results were assessed by summing area score and intensity score. All results were presented in frequency tables. Results and Discussion: There were about $6.7 \%$ patients in $61-70$ years age group and $4.2 \%$ patients with high PSA showing high VDR expression. Based on grade group, the lower grade group, the stronger VDR expression. Conclusion: Weak VDR expression was most often found in 51-60 years age group; high PSA value; Gleason score $3+4=7$ and $4+4=8$; moderately differentiated and poorly differentiated; and also grade group 4. Moderate and strong VDR expression was most often found in 61-70 years age group and high PSA. Moderate VDR expression was also most often found in Gleason score $4+5=9$, poorly differentiated, and grade group 5. Meanwhile, strong VDR expression was most often found in Gleason score $3+4=7$; moderately differentiated and grade group 2.
\end{abstract}

Keywords: vitamin D, VDR, prostate adenocarcinoma

\section{INTRODUCTION}

$\mathrm{P}$ rostate adenocarcinoma is an invasive carcinoma consisting of neoplastic prostate epithelial cells with differentiation and secretion arranged in various histomorphological patterns. In this carcinoma, basal cells are generally not found. ${ }^{1}$ Prostate adenocarcinoma is one of leading causes of death in men. Each year 1.6 millions men are diagnosed as prostate adenocarcinoma and 366,000 men die because of this tumor around the world. ${ }^{2}$ In 2019, prostate adenocarcinoma ranked in first most frequent cancer diagnosis with total new cases 174,650 (20\%) and second leading cause of death in men after lung cancer with total cases of 31,620 cases $(10 \%)$ in USA. ${ }^{3}$ In Asia, the mean incidence of prostate cancer is 7.2 per 100,000 men per year. ${ }^{4,5}$ In North Sumatra in 2016, prostate cancer ranked in $4^{\text {th }}$ after lung, cervical, and breast cancer with 42 cases. $^{6}$ In Medan in 2014 based on health center recapitulation, there were 99 prostate cancer patients ranking in $2^{\text {nd }}$ after breast cancer ( 499 cases). ${ }^{7}$

Prostate tissue is influenced by two steroid hormones, i.e. testosterone and vitamin $\mathrm{D}$. The action of these hormones are mediated by androgen receptor (AR) and VDR, respectively. Active hormone form of vitamin D is 1,25-dihydroxyvitamin D by inhibiting angiogenesis growth and metastasis in cancer cells. ${ }^{8}$ Vitamin D has been recognized as one of hormones and has been known to have a lower risk in some cancers, including prostate cancer. ${ }^{9}$ The function of nuclear transcription of VDR is to regulate transcription factors and mediate the action of vitamin $D$ in protein synthesis and contribute to bone mineral homeostasis and regulation of cell cycle. ${ }^{10}$

The role of vitamin D in various diseases and cancers has received much attention and has been widely studied in a number of researches. The first immunohistochemical comparative study in 27 samples from various age category of 10-19 years old, 2029 years old, 30-39 years old, 40-49 years old, 50-59 years old, and 60-69 years old, showed that the weakest VDR expression is found in 10-19 years age group, which increase in 20-59 years old, and decrease in 60-69 years old. ${ }^{11}$ The latest study about VDR protein expression in 841 prostate cancer patients showed that men with high VDR expression showed decrease in PSA value, Gleason score, and stagnant tumour stage; therefore, significantly reduce the risk of lethal malignancy of prostate cancer. ${ }^{9,12}$

VDR in human prostate hasn't been studied much so that it can be used as a subject for further research. Based on previous studies, there are still discrepancy in the results obtained. According to Krill et al. in 2001, immunohistochemical staining in prostate tumour tissue was expressed in nuclei, ${ }^{11}$ meanwhile based on Hendrickson et al in 2011, it was expressed in cytoplasms/membrane. ${ }^{9}$ Vitamin D serologic examination hasn't yet been carried out as a prognostic indicator for prostate adenocarcinoma at referral hospital so it was difficult to obtain blood samples vitamin $\mathrm{D}$ value, whereas it is known that vitamin $\mathrm{D}$ is beneficial in inhibiting poorer prognosis in prostate adenocarcinoma. This study hasn't been done in Indonesia, especially in Medan. This study aimed to assess the distribution 
of VDR immunohistochemical expression in prostate adenocarcinoma based on age, PSA value, and histopathological grading.

\section{MATERIAL AND METHODS}

\section{Sample selection}

This descriptive research with cross sectional approach was done in General Hospital H. Adam Malik Medan/ Department of Anatomical Pathology, Medical Faculty USU. This study was conducted from June 2020 until May 2021, after receiving approval from Health Research Ethics Committee, Medical Faculty Universitas Sumatera Utara Medan.

Study samples were gathered from paraffin blocks from patients diagnosed as prostate adenocarcinoma cases in General Hospital H. Adam Malik Medan/ Department of Anatomical Pathology, Medical Faculty USU fulfilling inclusion and exclusion criteria. Samples were gathered by using total sampling. Inclusion criteria in this study were paraffin blocks from TURP, prostatectomy and core biopsy specimens that has been histopathologically diagnosed as prostate adenocarcinoma, are adequate after stained with hematoxylin-eosin, and adequate medical record including age and PSA level. Meanwhile, exclusion criteria were incomplete medical record (no age and PSA level), paraffin blocks with core biopsy specimens $<10$, and paraffin blocks/ slides that are not fulfilling standard (damaged, etc.). Each samples were stained with HE and VDR polyclonal antibody immunohistochemistry (Bioassay technology laboratory, dilution 1:100-1:300).

After that, review slides by researcher and two pathologists supervisors were done. PSA level was categorized into normal (value $\leq 4.0 \mathrm{ng} / \mathrm{ml}$ ), moderate $(4.1-10 \mathrm{ng} / \mathrm{ml})$, and high (>10ng/ml). ${ }^{13}$ To evaluate histopathological grading in this study, the researchers use two versions, which are based on Gleason score and grade group. According to Gleason score, histopathological grading are categorized into well differentiated (Gleason score $\leq 6$ ), moderately differentiated (Gleason score 7), and poorly differentiated (Gleason score $8-10) .{ }^{14}$ On the other hand, based on grade group, histopathological grading are categorized into: Grade group 1 (Gleason score $\leq 6$ ), Grade group 2 (Gleason score 3+4), Grade group 3 (Gleason score 4+3), Grade group 4 (Gleason score $4+4=8,3+5=8,5+3=8$ ), and Grade group 5 (Gleason score 9-10). ${ }^{15}$

Then, the assessment of VDR expression in prostate adenocarcinoma samples was done. VDR expression was determined by brown appearance in cytoplasms and nuclei. VDR expression score was obtained by adding up total area score and intensity score. Positive control was taken from gut specimen. Total area was done as follows: score 0 (if no positive stained nuclei and cytoplasms), score 1 ( $<10 \%$ of positive stained nuclei and cytoplasms), score 2 (10-50\% of positive stained cells), and score 3 ( $>50 \%$ of positive stained cells. Meanwhile, intensity was scored as follows: 0 (none), 1 (weak, light brown), 2 (moderate), and 3 (strong, dark brown). After that, the total score of VDR expression was categorized as weak (if total score $\leq 2$ ), moderate (if total score 3-4), and strong (total score 5-6). ${ }^{9,16}$

\section{Data analysis}

Data collected in this research were processed by using statistical software and presented in frequency tables.

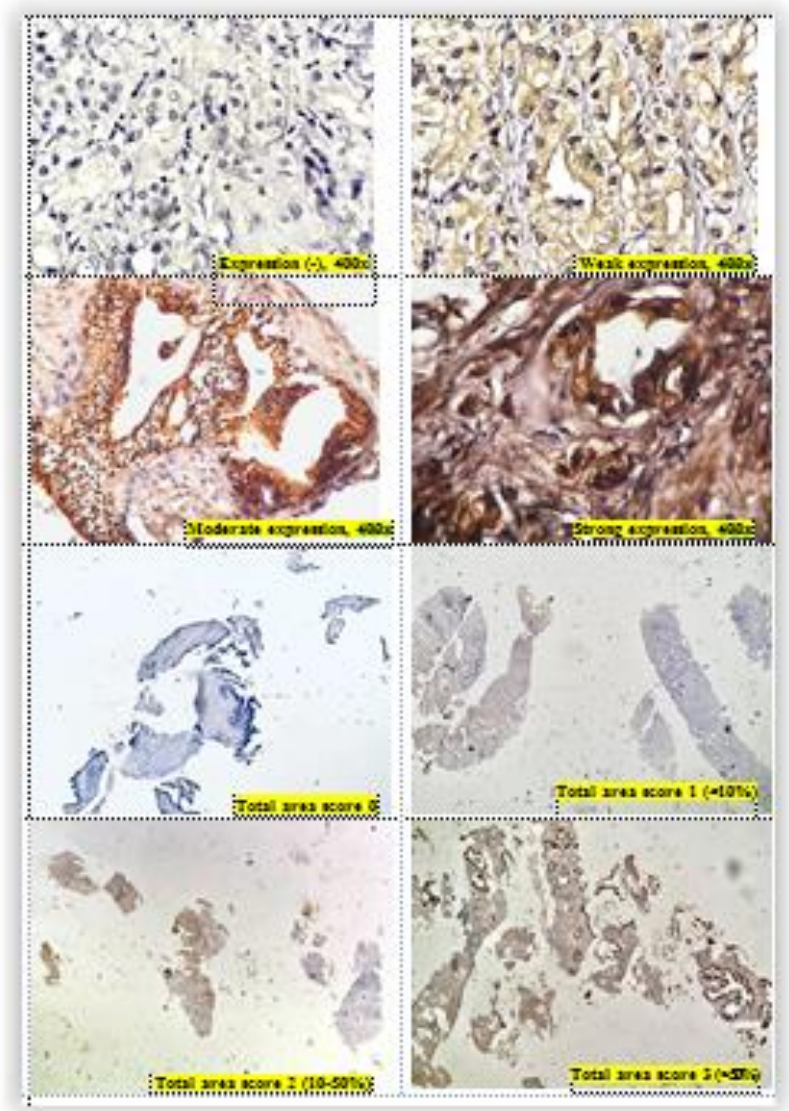

Figure 1. Interpretation of VDR immunohistochemical staining.

\section{RESULTS}

In this study, 34 samples with prostate adenocarcinoma diagnosis in Department of Anatomic Pathology, Faculty of Medicine, Universitas Sumatera Utara and Anatomic Pathology Unit, General Hospital Haji Adam Malik Medan were obtained. In this study, analysis about the distribution of VDR immunohistochemical expression in prostate adenocarcinoma based on age, PSA level, and grading histopathology was done. This research showed that weak VDR expression was most common found in 51-60 years age group (50\%) and high PSA level $(62.5 \%)$. Moderate VDR expression was most common found in 61-70 years age group (48\%) and high PSA level (72\%). Strong VDR expression was most common in 61-70 years age group $(6.7 \%)$ and high PSA level (100\%) (Table 1).

Besides that, analysis about the frequency distribution of VDR expression based on grading histopathology was done. Weak VDR expression was most common found in Gleason score $3+4=7$ and $4+4=8$ (respectively $37.5 \%$ ); moderately 
differentiated and poorly differentiated (respectively 50\%); and grade group $4(50 \%)$. Moderate VDR expression was most common found in Gleason score $4+5=9 \quad(24 \%)$; poorly differentiated (72\%); and grade group 5 (56\%). Strong VDR expression was most common in Gleason score 3+4=7 (100\%); moderately differentiated $(100 \%)$; and grade group $2(100 \%)$.

Table 1. Frequency distribution of VDR expression based on age and PSA level.

\begin{tabular}{|c|c|c|c|c|c|c|c|}
\hline \multirow[t]{2}{*}{ Variables } & \multicolumn{6}{|c|}{ Expression VDR } & \multirow[t]{2}{*}{ Total } \\
\hline & Weak & $\%$ & Moderate & $\%$ & Strong & $\%$ & \\
\hline $\begin{array}{l}\text { Age (years } \\
\text { old) }\end{array}$ & & & & & & & \\
\hline $\begin{array}{r}\leq 40-50 \\
51-60 \\
61-70 \\
>70\end{array}$ & $\begin{array}{l}0 \\
4 \\
2 \\
2\end{array}$ & $\begin{array}{c}0 \\
50 \\
25 \\
25\end{array}$ & $\begin{array}{c}3 \\
5 \\
12 \\
5\end{array}$ & $\begin{array}{l}12 \\
20 \\
48 \\
20\end{array}$ & $\begin{array}{l}0 \\
0 \\
1 \\
0\end{array}$ & $\begin{array}{c}0 \\
0 \\
100 \\
0\end{array}$ & $\begin{array}{c}3 \\
9 \\
15 \\
7\end{array}$ \\
\hline "PSA level" & & & & & & & \\
\hline $\begin{array}{l}\text { Normal } \\
\text { Moderate }\end{array}$ & $\begin{array}{l}3 \\
0\end{array}$ & $\begin{array}{c}37,5 \\
0\end{array}$ & $\begin{array}{l}5 \\
2\end{array}$ & $\begin{array}{c}20 \\
8\end{array}$ & $\begin{array}{l}0 \\
0\end{array}$ & $\begin{array}{l}0 \\
0\end{array}$ & $\begin{array}{l}8 \\
2\end{array}$ \\
\hline High & 5 & 62,5 & 18 & 72 & 1 & 100 & 24 \\
\hline Total & 8 & 100 & 25 & 100 & 1 & $100^{\circ}$ & 34 \\
\hline
\end{tabular}

Table 2 Frequency distribution of VDR expression based on grading histopathology

\begin{tabular}{|c|c|c|c|c|c|c|c|}
\hline \multirow{2}{*}{ Gradinghistopathology } & \multicolumn{6}{|c|}{ Expression $V D R$} & \multirow[t]{2}{*}{ Total } \\
\hline & Weak & $\%$ & Moderate & $\%$ & Strong & $\%$ & \\
\hline \multicolumn{8}{|l|}{ Gleas on score } \\
\hline $2+3=5$ & 0 & 0 & 2 & 8 & 0 & 0 & 2 \\
\hline $3+3=6$ & 0 & 0 & 2 & 8 & 0 & 0 & 2 \\
\hline $3+4=7$ & 3 & 37,5 & 3 & 12 & 1 & 100 & 7 \\
\hline $4+3=7$ & 1 & 12,5 & 0 & 0 & 0 & 0 & 1 \\
\hline $3+5=8$ & 0 & 0 & 1 & 4 & 0 & 0 & 1 \\
\hline $4+4=8$ & 3 & 37,5 & 2 & 8 & 0 & 0 & 5 \\
\hline $5+3=8$ & 1 & 12,5 & 1 & 4 & 0 & 0 & 2 \\
\hline $4+5=9$ & 0 & 0 & 6 & 24 & 0 & 0 & 6 \\
\hline $5+4=9$ & 0 & 0 & 3 & 12 & 0 & 0 & 3 \\
\hline $5+5=10$ & 0 & 0 & 5 & 20 & 0 & 0 & 5 \\
\hline \multicolumn{8}{|l|}{ Grade histopathology } \\
\hline Well differentiated & 0 & 0 & 4 & 16 & 0 & 0 & 4 \\
\hline Moderately differentiated & 4 & 50 & 3 & 12 & 1 & 100 & 8 \\
\hline Poorly differentiated & 4 & 50 & 18 & 72 & 0 & 0 & 22 \\
\hline \multicolumn{8}{|l|}{ Grade group } \\
\hline Grade group 1 & 0 & 0 & 4 & 16 & 0 & 0 & 4 \\
\hline Grade group 2 & 3 & 37,5 & 3 & 12 & 1 & 100 & 7 \\
\hline Grade group 3 & 1 & 12,5 & 0 & 0 & 0 & 0 & 1 \\
\hline Grade group 4 & 4 & 50 & 4 & 16 & 0 & 0 & 8 \\
\hline Grade group 5 & 0 & 0 & 14 & 56 & 0 & 0 & 14 \\
\hline Total & 8 & 100 & 25 & 100 & 1 & 100 & 34 \\
\hline
\end{tabular}

\section{DISCUSSION}

Prostate tissue is influenced by two steroid hormone, i.e. testosterone and vitamin D. $1,25(\mathrm{OH})_{2} \mathrm{D}_{3}$ is the most active vitamin $\mathrm{D}$ metabolite due to the highest affinity binding to VDR. This VDR has been found in prostate epithelium and cancer cells. ${ }^{17}$ In cellular level, vitamin D has anticancer effects through some mechanisms, such as inhibition of proliferation (through cessation of cell cycle), invasion and angiogenesis, sensitization to stimulus of apoptosis, induction of differentiation, and immune system regulation. ${ }^{8,9,18}$ In all cancer types, this combination of anticancer mechanism effects towards tumour and stroma cells maybe determine how vitamin D works. ${ }^{18}$ The most likely mechanism why G0/G1 phase of the cell cycle stop at prostate cancer cells that express VDR is inhibition of cyclindependent kinase inhibitor, i.e. p21 and p27, of which expression set differently by $1,25(\mathrm{OH})_{2} \mathrm{D}$, thereby inhibiting the development of the cell cycle in the $\mathrm{S}$ phase. In prostate cancer model, the exposure of $1,25(\mathrm{OH})_{2} \mathrm{D}$ can increase messenger and protein $\mathrm{p} 21$ rate. These effects will be potentiated in cases of combination therapy, such as in prostate cancer where vitamin D and Akt inhibitor cooperate in inducing the cessation of G1 phase of the cell cycle and cell aging, i.e. by inducing upregulation of $\mathrm{p} 21 .^{19}$

In prostate cancer cells, prolonged exposure to $1,25(\mathrm{OH})_{2} \mathrm{D}$ is able to induce apoptosis by stimulating pro-apoptotic factor Bax and Bad, by inhibiting antiapoptotic factor such as Bcl-2, and by stimulating caspase- 3 expression through downregulation of $\mathrm{Wnt} / \beta$-catenin pathway. Furthermore, the accumulation of $\beta$ catenin in nuclei can promote several oncogene transcription, including c-MYC, contributing to carcinogenesis and development of cancer cells, because c-MYC is involved in cell cycle. Moreover, vitamin D greatly contributes to the regulation of cytokines and prostaglandin and also inhibits NF-kB signaling. ${ }^{19}$

$1,25(\mathrm{OH})_{2} \mathrm{D}_{3}$ has two types of effects on target cells, i.e. genomic and non genomic pathways. Most researches indicate that these two effects are mediated by the binding of 1,25 $(\mathrm{OH})_{2} \mathrm{D}_{3}$ to VDR and activation of VDR. ${ }^{18}$ Genomic pathway (nuclei) occurs when vitamin $\mathrm{D}$, or in its active form, calcitriol binds with VDR forming heterodimer with retinoic $\mathrm{X}$ receptor (RXR) and with its ligand (nine cisretinoic acid). This dimer forms complex with Vitamin D response-related element through gene transcription to produce differentiation function. Nongenomic pathway (cytoplasms) is a rapid mechanism of VDR binding to calcitriol taking place in the VDR membrane on the caveolae plasma membrane. The binding of VDR to calcitriol in plasma membrane will activate some second messenger system. ${ }^{14}$ The presence of these two pathways is evident when VDR immunohistochemistry was partly stained in the nucleus and partly in the cytoplasm.

This study showed that almost all samples in all age category has moderate VDR expression. The only sample with strong VDR expression aged 61-70 years old (100\%). From 8 samples with weak VDR expression, there were 4 aged 51-60 years old (50\%), and 2 samples aged 61-70 years old and $>70$ years old, respectively (25\%). So far, researchers didn't find any studies associating age and VDR expression in oesophagus SCC patients. This study revealed that most of the patients aged $\leq 60$ years old and $>60$ years old together have low VDR expression. There were no differences in VDR expression in both age groups. ${ }^{20}$

There was one study by Krill et al about how VDR expression patterns in normal human prostate. They found that the lowest VDR expression was found in 10-19 years age group, which increase in 20-59 years age group and decrease in 60-69 years age group. However, there was a reduction of VDR expression about $22 \%$ at 50-59 years old compared to 60-69 years old that was statistically not significant. It was not explained in this study why this can happen. ${ }^{11}$ From this, it may be assumed that there may be a certain age tendency to have a strong VDR expression. Nevertheless, the results of this study should be investigated further. Campolina-Silva et al found that as the Wistar rats get older, their VDR expression level will increase, except in lesion areas with intraepithelial proliferation, metaplasia, and proliferative inflammatory atrophy. Any reduced expression of VDR is an important element in the histopathological changes in the aging prostate. Therefore, this 
VDR expression status should not be ignored if there is prostate disease. $^{21}$

Furthermore, based on PSA level in this study, the only sample with strong VDR expression has high PSA level (100\%). From 8 samples with weak VDR expression, there were 5 with high PSA level $(62.5 \%)$ and 3 normal $(37.5 \%)$. This study result was in accordance with Swami et al and Hendrickson et al. From these literatures, revealed that prostate carcinoma patients with high VDR expression showed reduction in PSA value., ${ }^{9,12}$

In this study, based on Gleason score, the only prostate adenocarcinoma sample with strong VDR expression has gleason score $3+4=7$ (100\%). From 8 samples with weak VDR expression, each 3 samples had gleason score $3+4=7$ and $4+4=8$ $(37.5 \%)$; and each 1 sample had gleason score $4+3=7$ and $5+3=8$ $(12.5 \%)$. Then, the only prostate adenocarcinoma sample with strong VDR expression was determined as moderately differentiated (100\%). From 8 samples with weak VDR expression, there were 4 samples with moderately differentiated and poorly differentiated prostate adenocarcinoma, respectively (50\%). This study seems to be in line with Hendrickson et al. They found that men with high VDR protein tumour expression have better clinical characteristics, including lower Gleason score. They also found that the highest VDR expression was in tumour with Gleason score $3+3=6$ and decreased with increasing Gleason score $(\mathrm{p}<0.001) .{ }^{9}$ In Jingwi et al, there was a association between single nucleotide polymorphism (SNP) VDR and Gleason score in prostate adenocarcinoma, i.e. there was an association between BsmI genotype and rs2239185 and high Gleason score. ${ }^{22}$ In this study, in all grade histopathology have diversity in VDR expression. It is possible that this is due to the difference in SNP VDR in study samples. Therefore, further researches about SNP VDR in this group samples was needed.

Based on grade group, the only prostate adenocarcinoma samples with strong VDR expression was defined as grade group $2(100 \%)$. From 8 samples with weak VDR expression, there were 4 samples with grade group 4 (50\%), 3 with grade group 2 $(37.5 \%)$, and 1 grade group $3(12.5 \%)$. In this study, it was also found that the stronger the VDR expression, then the lower the grade group. Ginting et al in their study divided grade group into three groups such as low (grade 1 and 2), moderate (grade 3), and high (grade 4 and 5). They showed that about $10 \%$ of low grade group had strong positive VDR expression, while $20 \%$ of high grade cases was also strong expressed in VDR. But, when statistically tested, it was found that there was no difference between the expression of VDR and prostate adenocarcinoma grade group. Besides that, it was also found that in all grade group, moderate VDR expression was found higher than the strong one. ${ }^{14}$

Increased expression of VDR in colorectal cancer is associated with better tumour differentiation, absence of lymph node involvement and better prognosis. In breast cancer, this increased expression of VDR was also related with slower metastasis to lymph node and longer disease-free survival. Besides that, the cellular response to $1,25(\mathrm{OH})_{2} \mathrm{D}_{3}$ mainly depends on VDR expression levels. ${ }^{18}$ Because some of these samples had moderate VDR expression, this showed that these samples can be treated with $1,25(\mathrm{OH})_{2} \mathrm{D}_{3}$ analog. If VDR downregulation occurrs, it will cause unresponsiveness and drug resistance not only to $1,25(\mathrm{OH})_{2} \mathrm{D}_{3}$ analog therapy but also antitumoral effects from $1,25(\mathrm{OH})_{2} \mathrm{D}_{3}$ endogenous.

During this study, there was difficulty experienced by researchers. First of all, in determining the grading, some of the samples were from core biopsy, so it is difficult for the researchers to obtain good enough tumour specimens. It is feared that it does tno represent the Gleason score and VDR expression. Second, in assessing VDR expression, the intensity of the brown color that appeared was not too different.

There were limitations encountered in this research. First, the researchers only evaluate the amount of VDR in tissues and not in blood samples. Therefore, it can't describe the actual vitamin D levels in the samples. Second, there was limitation in medical record data so the researchers can't dig deeper information related to prostate zone that having malignancy.

\section{CONCLUSION}

In this study, some conclusion could be emphasized. Weak VDR expression was most often found in 51-60 years age group; high PSA value; Gleason score $3+4=7$ and $4+4=8$; moderately differentiated and poorly differentiated; and also grade group 4 . Moderate and strong VDR expression was most often found in 61-70 years age group and high PSA. Moderate VDR expression was also most often found in Gleason score $4+5=9$, poorly differentiated, and grade group 5. Meanwhile, strong VDR expression was most often found in Gleason score $3+4=7$; moderately differentiated and grade group 2 .

\section{COMPETING INTERESTS}

The author has no financial interests relevant to the product or company described in this article.

\section{ACKNOWLEDGMENT}

We would like to thank all staff of the Department of Anatomical Pathology, University of North Sumatra, Private hospitals and private clinics in Medan, Indonesia for all their assistance and cooperation.

\section{ETHICAL APPROVAL}

Health Research Ethical Committee, Universitas Sumatera Utara, Medan, Indonesia approved this study.

\section{REFERENCES}

[1] Ulbright TM, Amin MB, Balzer B, Berney DM, Epstein JI, Guo C, Idrees MT, et al. Germ Cell Tumours: Seminoma. In: Moch H, Humphrey PA, Ulbright TM, Reuter VE (eds). World Health Organization Classification of Tumours of the Urinary System and Male Genital Organs, 4th ed. LyonFrance: IARC; 2016. p. 203-4.

[2] Pernar CH, Ebot EM, Wilson KM, Mucci LA. The Epidemiology of Prostate Cancer. Cold Spring Harb Perspect Med. 2018 Dec; 8(12):1-19. doi: 10.1101/cshperspect.a030361.

[3] American Cancer Society. Cancer Facts \& Figures 2019. Atlanta: American Cancer Society; 2019. P. 22-3.

[4] Purnomo BB. Tumor Urogenital. In: Dasar-Dasar Urologi, Edisi Kedua. Jakarta: Sagung Seto; 2003. p. 207. 
[5] Komite Penanggulan Kanker Nasional. Pedoman Nasional Pelayanan Kedokteran Kanker Prostat. Jakarta: Kementerian Kesehatan Republik Indonesia; 2017. p. 1-2.

[6] Irawan D. Penderita Kanker Banyak Terima Informasi Keliru [Internet]. 2017 [Cited on $1^{\text {st }}$ October 2020] . Available from: http://koransindo.com/page/news/2017-0521/4/23/Penderita_Kanker_Banyak Terima_Informasi_Keliru.

[7] Prawira, Munthe L. Kanker Payudara Masih Tinggi [Internet]. 2015 [Cited on $23^{\text {th }} \quad$ September 2020]. Available from: http://www.mdn.biz.id/n/145907/.

[8] Miller GJ. Vitamin D and Prostate Cancer: Biologic Interactions and Clinical Potentials. Cancer Metastasis Rev. 1998; 17(4):353-60.

[9] Hendrickson WK, Flavin R, Kasperzyk JL, Fiorentino M, Fang F, Lis R, et al. Vitamin D Receptor Protein Expression in Tumor Tissue and Prostate Cancer Progression. J Clin Oncol. 2011 Jun; 29(17):2378-85. doi: 10.1200/JCO.2010.30.9880.

[10] Miyamoto K, Kesterson RA, Yamamoto H, Taketani Y, Nishiwaki E, Tatsumi S, et al. Structural Organization of the Human Vitamin D Receptor Chromosomal Gene and Its Promoter. Mol Endocrinol. 1997 Jul; 11(8):1165-79. doi:10.1210/mend.11.8.9951.

[11] Krill D, DeFlavia P, Dhir R, Luo J, Becich MJ, Lehman E, et al. Expression Patterns of Vitamin D Receptor in Human Prostate. J Cell Biochem. 2001 Sep; 82(4):566-72. doi:10.1002/jcb.1185.

[12] Swami S, Krishnan A V, Feldman D. Vitamin D Metabolism and Action in the Prostate: Implications for Health and Disease. Mol Cell Endocrinol. 2011 Dec; 347(1-2):61-9. doi:10.1016/j.mce.2011.05.010.

[13] Kumar V, Abbas A, Aster. Cell Injury, Cell Death, and Adaptations. In: Perkins JA, editor. Robbins Basic Pathology, 10th ed. Philadelphia: Elsevier; 2018. p. 33-56.

[14] Ginting RNA, Anggraini DR, Sitorus MS. Vitamin D Receptor Immunoexpression in Benign and Malignant Prostate Tumors. Open Access Maced J Med Sci. 2020 Oct 19; 8(B):949-51. doi: 10.3889/oamjms.2020.5148.

[15] Moch H, Humphrey PA, Ulbright TM, Reuter VE. Tumor of Prostate. In: Moch H, Humphrey PA, Ulbright TM, Reuter VE (eds). World Health Organization Classification of Tumours of the Urinary System and Male Genital Organs, 4th ed. Lyon-France: IARC; 2016. p. 135-83.

[16] Guileyardo JM, Johnson WD, Welsh RA, Akazaki K, Correa P. Prevalance of Latent Prostate Carcinoma in Two U.S Population. J Natl Cancer Inst. $1980 ; 65: 311-6$

[17] Lou YR, Qiao S, Talonpoika R, Syvälä H, Tuohimaa P. The Role of Vitamin D 3 Metabolism in Prostate Cancer. J Steroid Biochem Mol Biol. 2004;92(4):317-25.
[18] Larriba MJ and Munoz A. Mechanisms of Resistance to Vitamin D Action in Human Cancer Cells. In: Holick M (ed). Vitamin D Nutrition and Health. USA: Humana Press; 2010. doi:10.1007/978-1-60327-303-9_15

[19] Negri M, Gentile A, de Angelis C, Monto T, Patalano R, Colao A, et al. Vitamin D - Induced Molecular Mechanisms to Potentiate Cancer Therapy and to Reverse Drug - Resistance in Cancer Cells. Nutrients. 2020; 12:1798. doi: 10.3390/nu12061798.

[20] Peng H, Yu J, Li F, Cui X, Chen Y. Decreased Vitamin D Receptor Protein Expression is Associated with The Progression and Prognosis of Esophageal Squamous Cell Carcinoma: A Multi-Ethnic Cohort Study from the Xinjiang, China. Int J Clin Exp Pathol. 2017;10(2):2340-50.

[21] Campolina-Silva GH, Maria BT, Mahecha GAB, Oliveira CA. Reduced Vitamin D Receptor (VDR) Expression and Plasma Vitamin D Levels are Associated with Aging - Related Prostate Lesions. The Prostate. 2018;1-15.

[22] Jingwi EY, Abbas M, Ricks-Santi L, Winchester D, Beyene D, Day A, et al. Vitamin D Receptor Genetic Polymorphisms are Associated with PSA Level, Gleason Score and Prostate Cancer Risk in African-American Men. Anticancer Research. 2015; 35:1549-58.

\section{AUTHORS}

First author- dr. Zuhri Madriah, Resident of the Department of Anatomical Pathology, Faculty of Medicine, Universitas Sumatera Utara, Medan, Indonesia, email ID: zuhrimardiah@gmail.com

Second Author- Dr. dr. Delyuzar, M.Ked (PA) Sp.PA (K). Department of Anatomical Pathology, Faculty of Medicine, Universitas Sumatera Utara, Medan, Indonesia.

The third author- Dr. dr. Lidya Imelda Laksmi, M.Ked (PA), Sp.PA, Department of Anatomical Pathology, Faculty of Medicine, Universitas Sumatera Utara, Medan, Indonesia.

Correspondence Author- Dr. dr. Lidya Imelda Laksmi, M.Ked (PA) Sp.PA Department of Anatomical Pathology, Faculty of Medicine, Universitas Sumatera Utara, Medan, Indonesia, email ID:lidyaimelda76@gmail.com 